Proc. Estonian Acad. Sci. Biol. Ecol., 2003, 52, 3, 319-331

\title{
A specific impact of waves of fast ferries on sediment transport processes in Tallinn Bay
}

\author{
Tarmo Soomere* and Jüri Kask
}

Marine Systems Institute, Tallinn Technical University, Akadeemia tee 21, 12618 Tallinn, Estonia; jyri.kask@phys.sea.ee

Received 28 February 2003, in revised form 21 May 2003

\begin{abstract}
Tallinn Bay is a semi-enclosed basin in the Gulf of Finland with a mild wave regime and an exceptionally heavy density of high speed ship traffic. Several implications resulting from the difference between the periods of wind waves (typically 3-4 s, maximum 7-8 s in extreme storms) and waves excited by fast ferries (10-15 s) are described. It is shown that ship-generated waves may play a decisive role in certain coastal processes. They cause unusually high near-bottom velocities at depths of 5-25 m. The influence of ship waves may trigger an additional sediment transport mechanism and cause considerable changes in the existing balance of sediment transport processes.
\end{abstract}

Key words: fast ferry wakes, ship-generated waves, sediment transport, Gulf of Finland, coastal processes.

\section{INTRODUCTION}

Wakes of both traditional and fast ferries have frequently caused severe erosion problems in narrow and shallow straits of the Baltic Sea (e.g. Kohonen et al., 2001; Forsman, 2001). It has been generally believed that the ship wake wash is negligible in the open sea areas where ship traffic is sparse and natural waves are frequently much higher than the highest wakes. This assumption is indeed true for open ocean coasts exposed to high tidal waves, severe windseas, or intense swell. Their joint impact typically exceeds greatly that of anthropogenic ones.

In semi-enclosed seas some of these natural wave field components are frequently insignificant. In the Baltic Sea the influence of tidal waves on beach processes is negligible. Owing to the relatively small size of this basin the overall intensity of swell is moderate and typical swell periods insignificantly exceed the

* Corresponding author, tarmo@phys.sea.ee 
periods of storm waves. Certain coastal processes (erosion, sediment transport on the nearshore, and accumulation) are thus mostly governed by joint influence of local currents and wind waves.

The complex shape of the Baltic Sea (Fig. 1) combined with specific features of the local wind regime result in a high variability of the wave regimes in its different parts (Jönsson et al., 2002). The wave fields in the Gulf of Finland develop under the impact of features specific to elongated basins. First, the dominating wind directions frequently coincide with the axis of the basin (Launiainen \& Laurila, 1984; Soomere \& Keevallik, 2003). Secondly, wind waves have a tendency to line up along the axis of relatively narrow sea areas (Donelan et al., 1985; Pettersson et al., 2003). As a result, the wave field is often highly anisotropic and its most energetic components propagate along the basin axis. Consequently, high waves seldom penetrate into semi-enclosed bays of the central narrow part of the Gulf of Finland. Such bays have a mild natural wave regime and, owing to the above reasons, the structure of bottom sediments has evidently been adapted to small near-bottom velocities. Shallow areas of such bays may be vulnerable to an abrupt increase in wave activity.

Tallinn Bay in the central part of the Gulf of Finland is an example of a relatively well-sheltered sea region. The area between the Estonian and Finnish capitals, Tallinn and Helsinki, has apparently the heaviest high speed ship traffic among the open sea areas of the Baltic Sea. Up to 70 crossings of the bay take place daily during the high navigation season. Although severe windseas with the significant wave height exceeding $4 \mathrm{~m}$ may occur in this bay during extreme storms from specific directions, the local wave climate is mild as compared to the wave regime in the Baltic Proper or in the open part of the Gulf of Finland (Soomere, 2003).
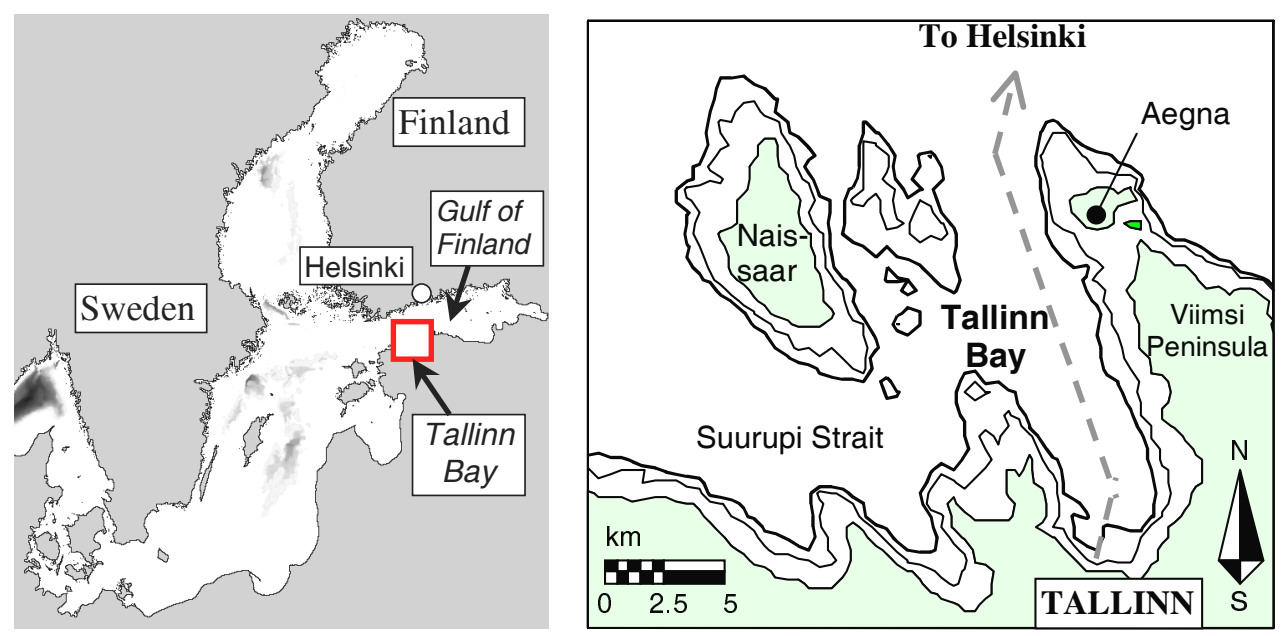

Fig. 1. Location and bathymetry of Tallinn Bay. Depth isolines at $10 \mathrm{~m}$ and $20 \mathrm{~m}$ (bold line) are shown. Dashed line shows the Tallinn-Helsinki ship lane. 
Recently, an extensive study of the properties of natural and ship-generated waves in different parts of the coast of Tallinn Bay was performed (Soomere et al., 2002, 2003). It focused on the relative impact of waves of different origin on the coastal processes in the immediate neighbourhood of the shoreline. Waves excited by fast ferries (for simplicity called ship waves below) have generally a modest height. The highest ship waves occurring during a navigation day nevertheless belong to the $1-5 \%$ of the highest waves occurring annually in the coastal zone. Still, it was concluded that the direct impact of ship waves on backshore as well as on beach processes at water depths $0-5 \mathrm{~m}$ is moderate and that ship wake wash does not, at least explicitly, cause any severe intensification of coastal erosion (Soomere et al., 2002, 2003).

The study also discovered that the most important difference between the high speed ship waves and the wind waves consists in extraordinarily long periods of ship waves. The periods of wind waves are typically 3-4 s and only in extreme storms they reach 7-8 s. The typical periods of the highest components of the wakes of fast ferries exceed $8 \mathrm{~s}$ and are frequently $12-15 \mathrm{~s}$, whereas wakes of conventional ships mostly consist of waves with periods of 3-4 s (Soomere \& Rannat, 2003).

On the one hand, this property of wind waves is one of the main reasons why storm waves are frequently relatively short and, consequently, particularly dangerous to ships in the Baltic Sea. On the other hand, the energy of short waves is concentrated in a rather thin upper layer of the sea and their influence only becomes evident in a relatively shallow part of the coastal zone.

As the energy of wave-induced motions decreases in a specific manner when the water depth increases (see below), long ship waves of modest height may cause uncommonly strong orbital velocities at certain depths compared to extreme storm waves. The difference in wave periods becomes dramatically evident in a more detailed comparison of ship and wind waves. Whilst the mean energy of ship waves in different parts of Tallinn Bay forms no more than $8 \%$ of the wind wave energy, the energy flux of ship waves (equivalent to the wave power) may be as high as $35 \%$ of the wind wave power (Soomere et al., 2003).

This paper describes several possible but important implications on the coastal processes in Tallinn Bay resulting from this difference in wave periods. The main properties of natural and ship waves in the coastal zone of Tallinn Bay are depicted according to an earlier research (Soomere et al., 2002, 2003). The relative role of the impact of waves with different periods on sea bottom is discussed. A qualitative sketch of a possible new pattern of the underwater sediment transport processes that may be caused by long ship waves in the deeper part of the coastal zone is presented.

\section{TYPICAL PROPERTIES OF WAVES OF DIFFERENT ORIGIN}

In terms of wave heights, the wind wave regime in Tallinn Bay is mild as compared to the Baltic Proper or to the open part of the Gulf of Finland. With the probability of $50 \%$ the significant wave height does not exceed $0.25 \mathrm{~m}$. (The 
estimates describe the wave properties in deep water whereas in the surf zone waves may be higher. The significant wave height $H_{\mathrm{s}}$ is the average height of $1 / 3$ of the highest waves.) With the probability of $99 \%$ the significant wave height does not exceed 1.25-1.5 m even in the central area of the bay (whereas for the waves of the adjacent domain of the Gulf of Finland this threshold is 2.0-2.5 m; Soomere et al., 2002; Soomere, 2003). In other words, only in 3-4 days a year $H_{\mathrm{s}}>1.5 \mathrm{~m}$ in the bay.

The maximum significant wave height once a year (also called 1-year return value of $H_{\mathrm{s}}$ ) does not exceed 2.1-2.2 m. The adjacent areas of the Gulf of Finland have a much severer wave regime: usually, the significant wave height exceeds $2.5 \mathrm{~m}$ in $3-4$ days a year and reaches about $3.5 \mathrm{~m}$ once a year.

During the relatively calm summer season the maximum wave heights in Tallinn Bay are about $25 \%$ smaller than in the stormy winter season. There also exist several coastal areas in the western part of the bay where wave heights are 20-30\% smaller than in the rest of the bay (Soomere, 2003).

Since the local fetch length is relatively small, periods of even the highest waves occurring in Tallinn Bay are relatively short (Orlenko, 1984). This conclusion was confirmed by direct measurements (Soomere \& Rannat, 2003). Wave periods during moderate winds $(6-10 \mathrm{~m} / \mathrm{s})$ typically did not exceed $3 \mathrm{~s}$ (Fig. 2a). Strong winds with a mean speed of $10-13 \mathrm{~m} / \mathrm{s}$ produced waves with peak periods up to $5 \mathrm{~s}$.
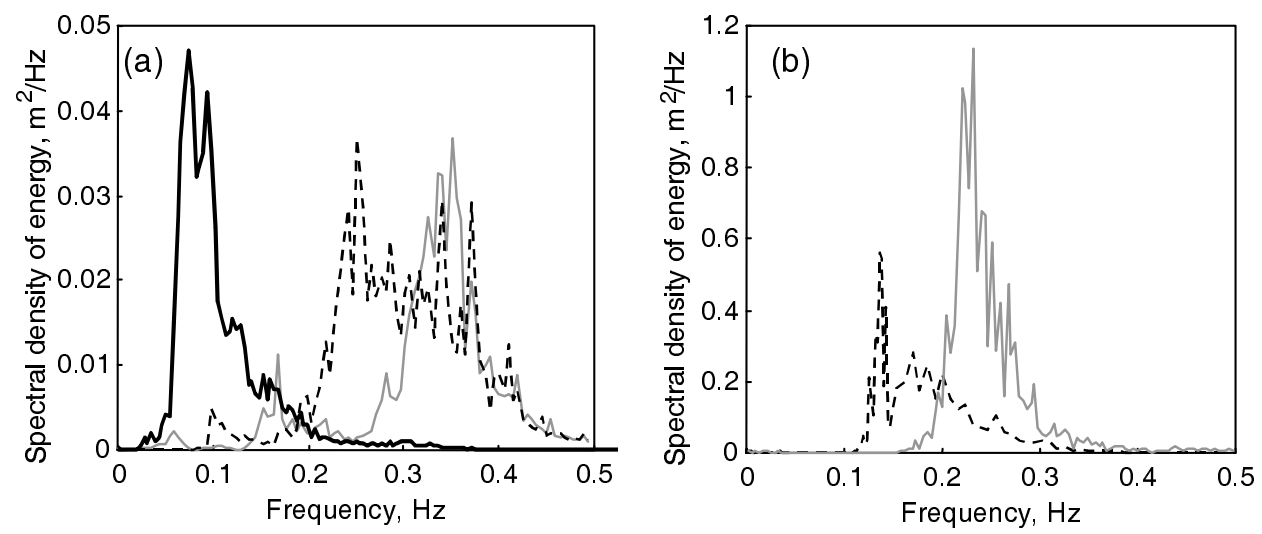

Fig. 2. Spectral density (spectrum) of wave energy near the eastern coast of Tallinn Bay at a depth of 5-6 m: (a) wind wave spectrum in the initial phase (grey line, $H_{\mathrm{s}}=52 \mathrm{~cm}$, local maxima at $0.06 \mathrm{~Hz}$ and $0.16 \mathrm{~Hz}$ are caused by ship waves) and after spectral saturation (dashed line, $H_{\mathrm{s}}=54 \mathrm{~cm}$ ) during a moderate wind (about $8 \mathrm{~m} / \mathrm{s}$ ), and spectrum of ship waves (solid line) at a distance of about $2 \mathrm{~km}$ from the ship lane; (b) wind wave spectrum at the maximum wind speed of a storm on 22.06 .2002 with a mean wind speed of $16-18 \mathrm{~m} / \mathrm{s}$ (grey line, $H_{\mathrm{s}}=151 \mathrm{~cm}$ ) and in swell-dominated seas in the final phase of this storm (dashed line, $H_{\mathrm{s}}=96 \mathrm{~cm}$ ). The spectra of wind waves were computed from wave recordings with a duration of $34 \mathrm{~min}$. The spectrum of ship waves represents average wave conditions during $10 \mathrm{~h}$ in calm conditions at the southwestern coast of Aegna on 14.04.2002. The vertical axis represents the spectral density of energy $\left(\mathrm{m}^{2} / \mathrm{Hz}\right)$. The wave height is proportional to the square root of the area between the curve representing a wave spectrum. Notice that the vertical scale is different on the different panels. 
Peak periods in strong storms where the significant wave height reaches its 1 -year return value did not exceed $6 \mathrm{~s} \mathrm{(Fig.} \mathrm{2b).} \mathrm{The} \mathrm{dominating} \mathrm{period} \mathrm{of} \mathrm{swell}$ during and after strong storms reached 7-8 s in extreme cases (Fig. 2a) but the corresponding wave heights were $<0.5 \mathrm{~m}$ (Soomere \& Rannat, 2003).

The height of a high speed ship wake is generally moderate. In coastal areas that lie $2-3 \mathrm{~km}$ from the ship lane each passing of a fast ferry causes a wake lasting about $10 \mathrm{~min}$. The properties of wakes in different coastal areas are described in detail in (Soomere \& Rannat, 2003). The highest waves occurred near Aegna Island (Fig. 1) where they exceeded $1 \mathrm{~m}$ in several wakes during a measurement day (Fig. 3). The maximum height of individual waves excited by a single ferry is typically about $60-80 \mathrm{~cm}$. In the more remote coastal zone of Naissaar Island (Fig. 1, about 8-10 km from the ship lane) the duration of wakes is up to one hour but wave heights are about $20-40 \mathrm{~cm}$. Much higher waves have been registered occasionally. Within 15 days of ship wave recordings in 2002, single waves higher than $1.5 \mathrm{~m}$ were filed several times and once even a wave as high as $2.3 \mathrm{~m}$ occurred (Soomere \& Rannat, 2003). Such particularly high waves apparently form either owing to a superposition of waves excited by two or more ships or owing to a superposition of wind and ship waves.

A specific feature of fast ferry wakes is that their energy is mostly concentrated in wave components with periods exceeding $5 \mathrm{~s}$ (Fig. 2a; conventional ships mainly excite waves with $3-5$ s periods). Typically about $70-80 \%$ of a wake energy consists of waves with periods $>8 \mathrm{~s}$. Another crucial property of the wakes is that their highest part has typically also the longest period, which frequently reaches $12-15 \mathrm{~s}$.

The reason why such high and long waves occur at relatively large distances from the ship lane is that ships occasionally sail at speeds close to the critical

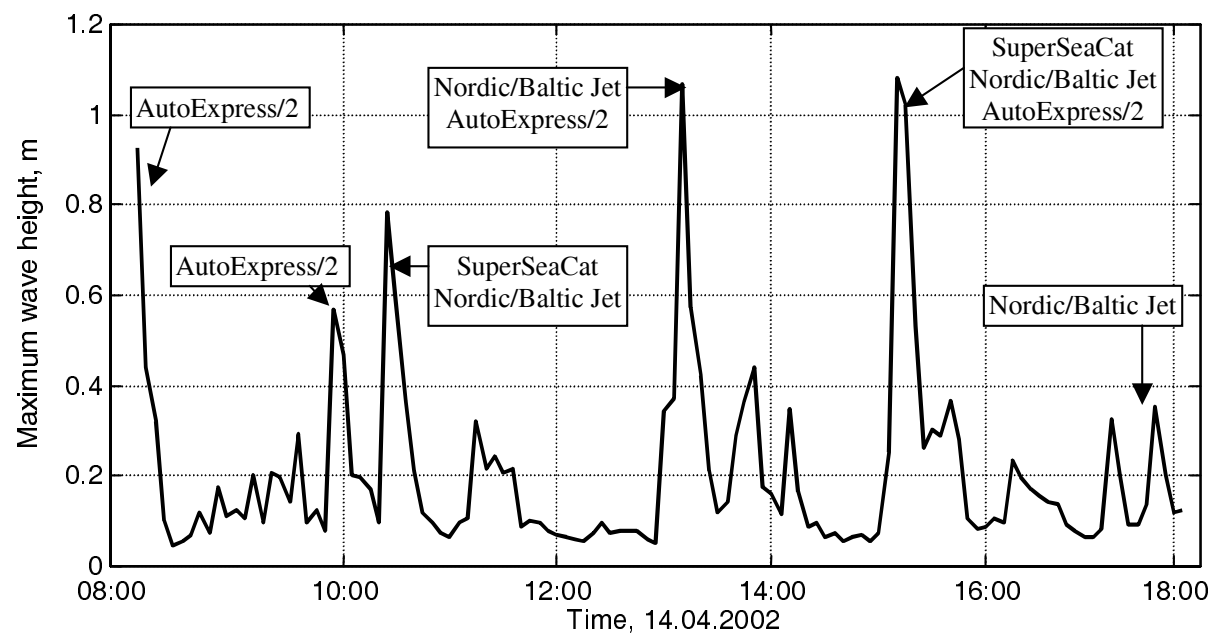

Fig. 3. Heights of ship-generated waves near Aegna in otherwise calm conditions (significant height of wind waves $<10 \mathrm{~cm}$ ). Only the names of the ships responsible for the highest measured waves are shown. 
velocity (which is $25-50$ knots in different parts of the ship lane). The resulting wave system disperses slowly and remains more or less coherent up to the coast (e.g. Sörensen, 1973; Chen \& Sharma, 1997).

\section{COMPARISON OF THE IMPACT OF SHIP WAKES AND WIND WAVES}

The difference in wave periods has huge consequences considering the impact of waves of different origin on bottom sediments. In the first approximation, the impact of a wave can be quantified in terms of the maximum orbital velocity $v_{\operatorname{maxb}}$ of water particles in the immediate neighbourhood of the bottom. If this velocity exceeds a specific threshold in particular geological conditions, bottom particles or components will start to move.

In the simplest approximation of linear waves, the velocity $v_{\operatorname{maxb}}$ depends on the wave amplitude $a$ (a half of the wave height), water depth $H$, and the wavelength $\lambda=2 \pi / k$ ( $k$ is the wave vector length) as follows (see any textbook on surface waves for details):

$$
v_{\operatorname{maxb}}=a \sqrt{\frac{2 g k}{\sinh 2 k H}} .
$$

Here $g$ is the gravity acceleration. The wave period $T$ is connected to the wave vector length through the dispersion relation $\omega^{2}=g k \tanh k H$, where $\omega=2 \pi / T$ is the wave frequency in radians. Longer surface waves have also larger periods. The velocity $v_{\operatorname{maxb}}$ depends linearly on the wave height: its increase (decrease) by, e.g., a factor of two results in an increase (decrease) of $v_{\text {maxb }}$ by the same factor.

For selected depths and for the wave height $1 \mathrm{~m}$ the dependence of this velocity on the wave period is shown in Fig. 4 . At depths $<5 \mathrm{~m}$ the near-bottom velocity fast increases when wave periods increase from 1 to $4 \mathrm{~s}$ and remains nearly constant for wave periods $>6 \mathrm{~s}$. Consequently, at these depths the difference between the periods of wind and ship waves causes only a minor increase in near-bottom velocities and the impact of a particular wave mainly depends on its height.

For larger depths the near-bottom velocities induced by wind waves with periods of a few seconds are much lower than those generated by long-period ship waves. For example, at a depth of $10 \mathrm{~m}$ a ship wave with a period of $12 \mathrm{~s}$ causes about twice as large near-bottom velocities as a wind wave with a period of $5 \mathrm{~s}$. Equivalently, the impact of a ship wave with a height of $1 \mathrm{~m}$ at this depth equals to that of a twice higher wind wave. At a depth of $20 \mathrm{~m}$, wind waves that are as high as about $6 \mathrm{~m}$ match the impact of $1 \mathrm{~m}$ high ship waves. The analysis in (Soomere et al., 2002; Soomere, 2003) suggests that in most of the coastal areas of Tallinn Bay wind waves with $2.5 \mathrm{~m}$ height are extremely rare and waves exceeding $5 \mathrm{~m}$ never occur. 


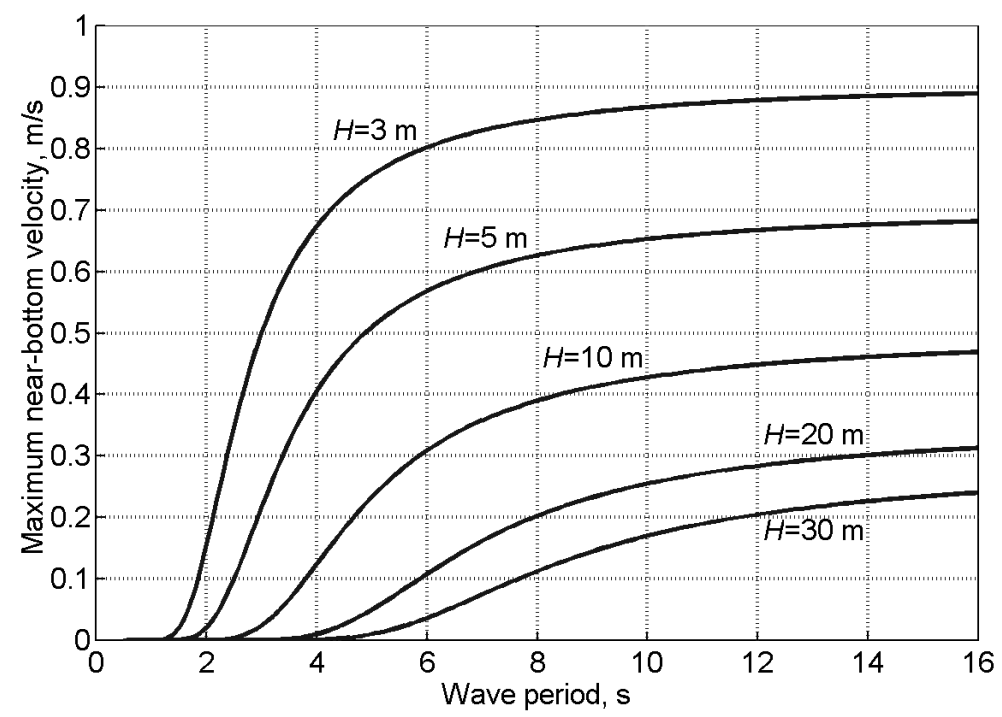

Fig. 4. The dependence of the maximum wave-induced near-bottom velocity on the wave period for the wave height $1 \mathrm{~m}$ and for the water depth $H$ of 3-30 m.

Obviously, the relative role of long-period ship waves further increases with increasing depth. However, for depths exceeding about $30 \mathrm{~m}$ even a wave with a period of about $15 \mathrm{~s}$ creates near-bottom velocities $\leq 20 \mathrm{~cm} / \mathrm{s}$. This velocity is comparable with the local current speeds at those depths in this sea area (e.g., Elken, 2002). Thus ship waves cause higher hydrodynamic activity than wind waves and local currents only in a specific part of the nearshore of Tallinn Bay, at depths of 5-25 m. The absolute values of estimated wave-induced near-bottom velocities at these depths are relatively high. For a ship wave with a height of $1 \mathrm{~m}$ and a period of $12 \mathrm{~s}$ they extend from about $70 \mathrm{~cm} / \mathrm{s}$ at a depth of $5 \mathrm{~m}$ to about $30 \mathrm{~cm} / \mathrm{s}$ at a depth of $25 \mathrm{~m}$ (Eq. (1)).

\section{A POTENTIAL NEW PATTERN OF SEDIMENT TRANSPORT IN THE COASTAL ZONE OF TALLINN BAY}

The geological structure of the deeper part of the bottom of Tallinn Bay is generally known (Talpas et al., 1994). However, the resolution of the existing data set is about $1 \mathrm{~km}$ and thus insufficient to describe features of bottom deposits in the coastal zone directly affected by ship waves (depths $\leq 30 \mathrm{~m}$, typical width $1-2 \mathrm{~km}$ ). A study of the geological setting of areas possibly endangered by fast ferry wakes showed that the shores of Tallinn Bay are often covered by coarsegrained terrigenous deposits (gravel, pebbles, cobbles), which overlie glacial deposits. On the foreshore $(0-1 \mathrm{~m})$ sand with gravel and pebble is spread. The same deposits occur in the depth interval 1-5 $\mathrm{m}$, but the share of sand is greater. 
In areas of intense hydrodynamic activity (where the sea floor deepens abruptly) in some shore sections of Tallinn Bay (ends of capes, the northwestern coast of Aegna) coarse-grained sediments (pebbles and cobbles) dominate in the depth interval 0-5 m (Kask et al., 2003).

In the depth interval 5-10 m the bottom deposits are usually represented by sand with some silt (up to $25 \%$ ). Between 10 and $20 \mathrm{~m}$ the sea floor is covered with silt containing ca $30 \%$ of pelite, and in places outcrops of glaciolacustrine deposits (varved clay) occur. The presence of fine-grained bottom sediments in the deeper part of the coastal zone (depths $>10$ m; Kask et al., 2003) of Tallinn Bay indicates low hydrodynamic activity.

As mentioned above, the abrupt increase of the ship wave loads during the last decade apparently plays a modest role in the sediment transport processes in backshore and at depths $0-5 \mathrm{~m}$ where natural wave activity dominates (Soomere et al., 2002). However, the analysis in the preceding sections suggests that ship waves probably dominate at certain depths where they excite velocities that occur extremely seldom under natural conditions. Therefore, they may trigger a more complicated pattern of sediment transport processes in Tallinn Bay.

Let us depict a highly idealized picture of the evolution of an initially smooth coastal profile (Fig. 5a). Assume that it first evolves solely owing to relatively short waves but, starting from a certain time instant, much longer waves appear. Assume also that, like it is typical of Tallinn Bay, the shore is covered with pebbles and cobbles, which overlie till. The initial evolution of the shore owing to the wave activity is described in classical texts and manuals (e.g. Wright $\&$ Short, 1984; Bruun, 1988; Coastal Engineering Manual, 2002, IV-3-51). Waves erode the shore in the immediate vicinity of the shoreline and transport finer sediments to the deeper area. At a certain distance from the original shoreline an abrasional scarp is formed (Fig. 5b). A part of the nearshore becomes less steep (the material eroded from the abrasional scarp is transported there) and after a while becomes nearly flat. The sedimentation is controlled by the grain size of the particles: the finer the particles and the larger the wave activity, the further away from the shoreline they are transported. Larger stones mostly retain their initial position. They occasionally cover a large part of the area directly influenced by waves and form a pavement protecting the shore from further erosion.

Whilst initially the erosion and transport processes are relatively fast, after some time they greatly slow down, because the flattened nearshore (where large waves usually break) and the pavement jointly protect the shore (Fig. 5c). At this stage, the evolution of the coastal zone has reached almost an equilibrium (as it has happened in Tallinn Bay). The shore profile, in particular the shape of the nearshore and the structure of its sediments, is basically defined by the local wind wave regime. It is only during very strong storms accompanied by unusually high water levels (such as the extreme storm in November 2001) that the shore erosion reinforces for short periods (Fig. 5d).

Wakes of fast ferries add a new forcing constituent to this scheme. As discussed above, in Tallinn Bay they apparently act effectively in the deeper part of the nearshore that often consists of relatively fine sediments and has no 
protecting pavement. Long ship waves may trigger a new stage of coastal zone evolution through fast eroding the seaside part of the nearshore and resuming the total transport of bottom sediments to the deeper area (Fig. 5e). The influence of ship waves is even greater during the main navigation season when sea level is often considerably $(20-30 \mathrm{~cm})$ lower than the annual mean.

There are no experimental data concerning the intensity and direction of the described sediment transport yet. However, the perceptible energy of wakes, the significantly high amount of ship wave power as compared to the bulk wave power, the existing structure of bottom sediments at depths of 10-25 m, and the estimates of the wave-induced near-bottom velocities (that are comparable to those excited by wind waves at depths of a few metres) suggest that its intensity might be comparable with that occurring in the initial stage of the erosion of a smooth coastal profile (Fig. 5a).

This transport may have twofold influence on the processes near the shoreline. First, it apparently creates a deficit of sediments in some intermediate part of the nearshore (next to the pavement), which will be balanced by a more intensive transport of material from the vicinity of the shoreline. Another, more subtle, consequence is that after some time the underwater plateau will become deeper, the intensity of wave breaking will decrease, and more wind wave energy will penetrate to the shoreline (Fig. 5f). As a result, the overall intensification of wave-induced sediment transport processes (possibly accompanied by a certain shoreline reduction) might be to a large extent higher than estimated earlier (Soomere et al., 2002, 2003) from plain energy-based quantities.

\section{CONCLUSIONS AND DISCUSSION}

Analysis of geological setting, nearshore processes, and wave activity in the Tallinn Bay area shows that usually ship waves are of modest height and they do not cause considerable direct shoreline erosion. The changes in the nearand backshore during the observation period (summer 2001-autumn 2002) were mostly due to the autumn-winter storms (Kask et al., 2003).

The wakes of fast ferries nevertheless may play a rather important role in the sediment transport processes. Although in extreme storms wind waves may be much higher than ship-generated waves, the daily highest ship waves belong to the highest $1-5 \%$ of all waves occurring annually in Tallinn Bay. They are noticeable in the total wave energy budget, too. Still the length of the highest components of ship wakes is the most important issue in estimates of their influence in the area in question. Long ship waves evidently cause unusually high near-bottom velocities (that several times exceed those excited by wind waves of comparable heights) in relatively deep areas, at depths of 5-25 m. This opinion is indirectly confirmed by the greatly reduced water transparency owing to fast ferry wakes in certain sea areas with a depth of about $10 \mathrm{~m}$ (Soomere et al., 2002).

In the long run, the abrupt increase of hydrodynamic activity in the deeper part of the nearshore may considerably change the existing sediment transport balance. 

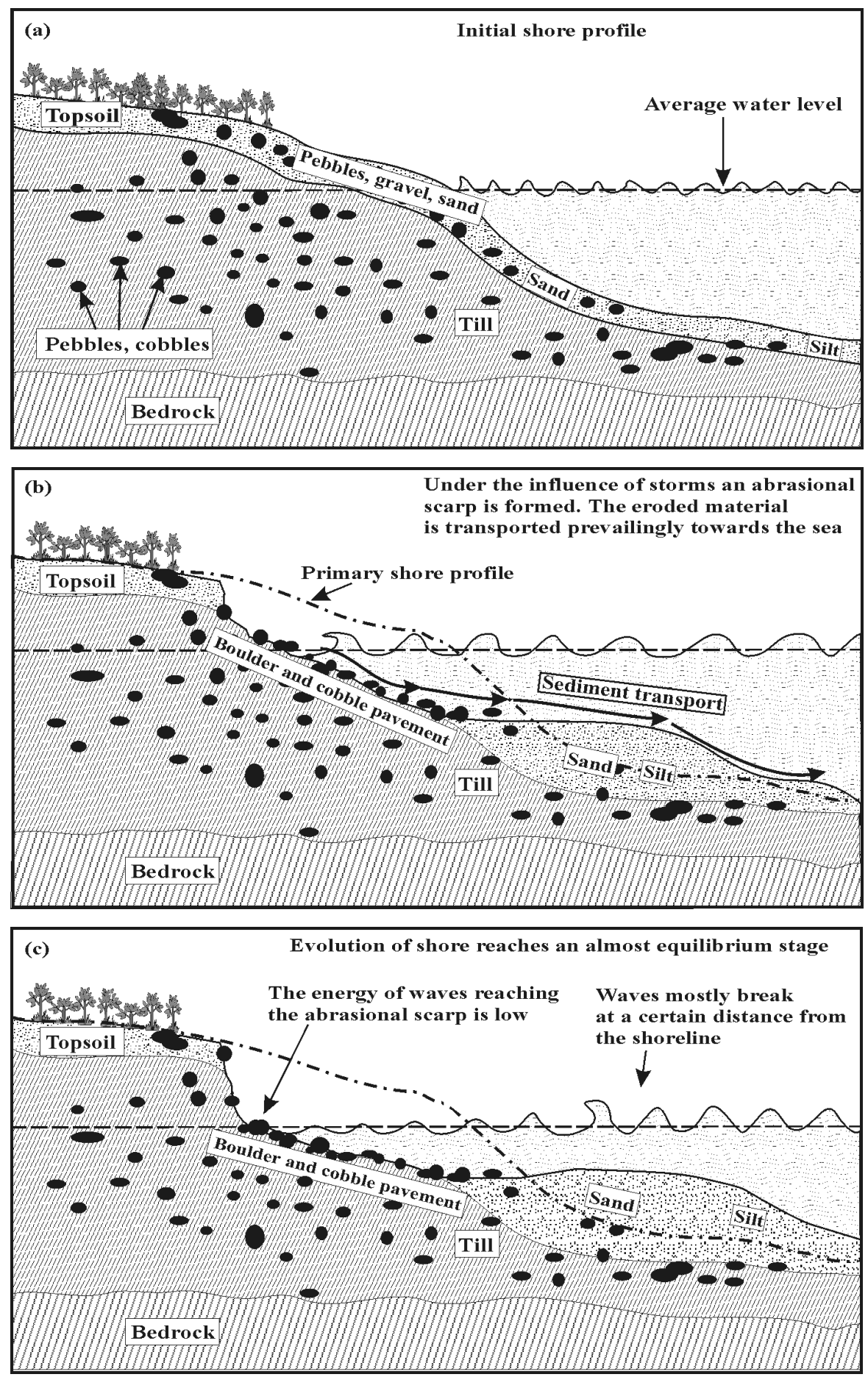

Fig. 5. Evolution of an initially smooth coastal profile (a-d, not to scale) and a possible effect of long ship waves (e, f). 

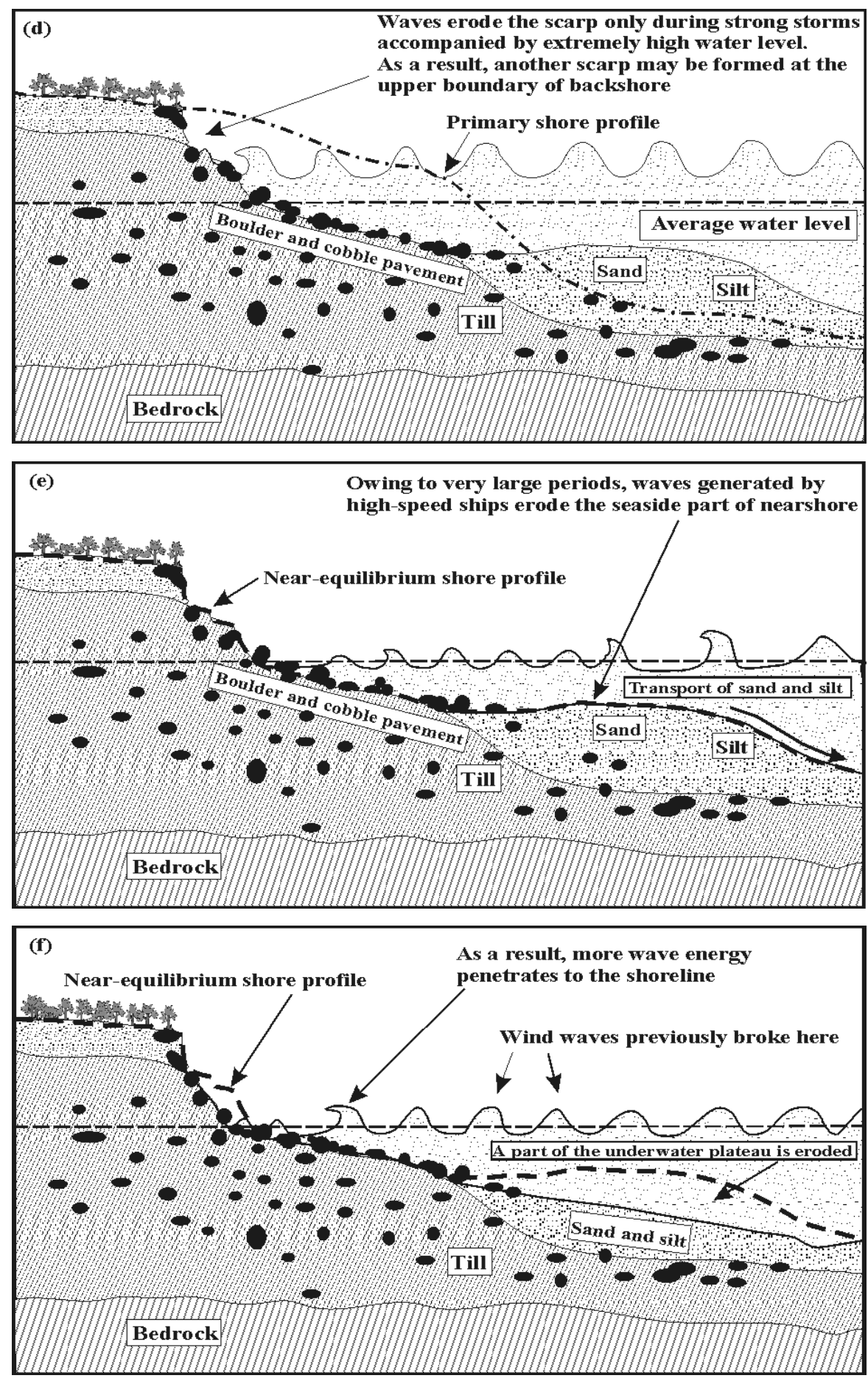

Fig 5. Continued. 
For ocean conditions it has been noticed that already relatively small levels of long-period swell energy in combination with wind waves can cause greater beach response than an equal amount of energy in only the windsea frequencies (Coates $\&$ Hawkes, 1999). An extensive joint influence occurs because waves with largely different periods (equivalently, waves of different origin in Tallinn Bay) generally transport sediments at different water depths. It would be extremely interesting and important to experimentally estimate the direction and intensity of the joint transport.

The above-discussed estimates in terms of wave energy, power, and waveinduced near-bottom velocity suggest that fast ferry wakes appear as a new forcing component in the bay. At least theoretically, they may cause considerable overall intensification of certain coastal processes. Moreover, we are facing a unique situation where a principally new component of the wave regime with an intensity comparable with that of the existing one has abruptly emerged in open sea conditions. This phenomenon has two main reasons: (1) Tallinn Bay is a nontidal area properly sheltered from high wind waves and open sea swell, and (2) the density of high speed ship traffic is so excessive that ship waves form a substantial part of the bulk wave intensity. Literally, the changes in the wave climate are comparable with those that would happen if open ocean swell from the North Atlantic reached the Gulf of Finland. As the intense fast ferry traffic has been present only a few years, this transport hopefully has not yet caused drastic changes in the deeper part of the coastal zone.

\section{ACKNOWLEDGEMENTS}

The study was mostly performed in the framework of the project "The influence of ship wakes on beaches of the Viimsi Peninsula and Naissaar and Aegna islands, and the possibilities of its neutralizing" (financed by the Estonian Environmental Investment Centre). Financial support of one of the authors (TS) from the Estonian Science Foundation (grant No. 4025) is gratefully acknowledged. Comments of two anonymous reviewers have greatly helped in improvement of the paper.

\section{REFERENCES}

Bruun, P. 1988. The Bruun Rule of erosion by sea-level rise: a discussion of large-scale two- and three-dimensional usages. J. Coastal Res., 4, 627-648.

Chen, X.-N. \& Sharma, S. 1997. On ships at supercritical speeds. In 21th Symposium on Naval Hydrodynamics, pp. 715-726. The National Academy of Sciences, USA.

Coastal Engineering Manual. 2002. Department of the Army. U.S. Army Corps of Engineers. Manual No. 1110-2-1100 (CD).

Coates, T. T. \& Hawkes, P. J. 1999. Beach recharge design and bi-modal wave spectra. In Coastal Engineering 1998: Proceedings of the 26th International Conference 22-26 June 1998, Falconer Hotel, Copenhagen (Edge, B. L., ed.), Vol. 3, pp. 3036-3045. American Society of Civil Engineers (ASCE), USA.

Donelan, M. A., Hamilton, J. \& Hui, W. H. 1985. Directional spectra of wind-generated waves. Philos. Trans. R. Soc. Lond., A315, 509-562. 
Elken, J. 2002. Hoovuste ja õlireostuse mudeli verifitseerimine hoovuseandmetega. In Muuga sadama merekeskkonnamõju seire 2002, hüdrodünaamika (Kõuts, T., ed.), pp. 99-110. Marine Systems Institute, Tallinn.

Forsman, B. 2001. From bow to beach. SSPA Highlights, 3, 4-5.

Jönsson, A., Broman, B. \& Rahm, L. 2002. Variations in the Baltic Sea wave fields. Ocean Eng., 30, 107-126.

Kask, J., Talpas, A, Kask, A. \& Schwarzer, K. 2003. Geological setting of areas endangered by waves generated by fast ferries in Tallinn Bay. Proc. Estonian Acad. Sci. Eng., 9, 185-208.

Kohonen, T., Rytkonen, J., Virtasalo, J. \& Vuorinen, I. 2001. Sediment erosion and resuspension near navigation routes and dredged material disposal sites. In Baltic Sea Science Congress 2001, Abstract volume, p. 226. Stockholm Marine Research Centre.

Launiainen, J. \& Laurila, T. 1984. Marine wind characteristics in the northern Baltic Sea. Finn. Mar. Res., 250, 52-86.

Orlenko, L. R. (ed.) 1984. Studies of the Hydrometeorological Regime of the Tallinn Bay. Leningrad, Gidrometeoizdat (in Russian).

Pettersson, H., Kahma, K. K. \& Tuomi, L. 2003. Predicting wave directions in a narrow bay. J. Phys. Oceanogr. (in press).

Soomere, T. 2003. Tallinna lahe loodusliku lainetuse režiimist. Publ. Inst. Geogr. Univ. Tartu., 93, 227-241.

Soomere, T. \& Keevallik, S. 2003. Directional and extreme wind properties in the Gulf of Finland. Proc. Estonian Acad. Sci., Eng., 9, 73-90.

Soomere, T. \& Rannat, K. 2003. An experimental study of wind waves and ship wakes in Tallinn Bay. Proc. Estonian Acad. Sci. Eng., 9, 157-184.

Soomere, T., Elken, J., Kask, J., Keevallik, S., Kõuts, T., Metsaveer, J. \& Peterson, P. 2002. Laevaliikluse purustav mõju Viimsi poolsaare, Aegna ja Naissaare randadele ning selle neutraliseerimise võimalused. Research report. Marine Systems Institute at Tallinn Technical University, Tallinn.

Soomere, T., Rannat, K., Elken, J. \& Myrberg, K. 2003. Natural and anthropogenic wave forcing in the Tallinn Bay, Baltic Sea. In Coastal Engineering VI (Brebbia, C. T., Almorza, D. \& López-Aguayo, F., eds.), pp. 273-282. WIT Press, Southampton, Boston.

Sörensen, R. M. 1973. Ship-generated waves. Advances Hydrosci., 9, 49-83.

Talpas, A., Väling, P., Kask, J., Mardla, A. \& Sakson, M. 1994. Balti mere šelfiala geoloogiline kaardistamine mõ̃tkavas 1:200000. Map sheets O-34-VI, O-34-XII, O-35-I,II. Research report. Estonian Geological Survey, Tallinn.

Wright, L. D. \& Short, A. D. 1984. Morphodynamic variability of surf zones and beaches: a synthesis. Mar. Geol., 56, 93-118.

\section{Kiirlaevade käigulainete mõjust setete transpordile Tallinna lahes}

\section{Tarmo Soomere ja Jüri Kask}

Soome lahe tormilainetuse eest hästi varjatud Tallinna lahes on mahe looduslik lainekliima ning erakordselt tihe kiirlaevade liiklus. Tuulelainete tüüpilised perioodid on 3-4 s (ekstreemsetes tormides 7-8 s), kuid kiirlaevade käigulainete perioodid on sageli 10-15 s. Pikad kiirlaevalained mõjutavad rannaprotsesse tunduvalt rohkem kui niisama kõrged looduslikud lained. Laevalainete mõju avaldub peamiselt 5-25 m sügavustes rannanõlva osades, kus need põhjustavad ebatavaliselt suuri põhjalähedasi vee kiirusi ning võivad muuta praegust rannaprotsesside tasakaalu. 